\title{
Interaction of cationic porphyrin-imidazophenazine conjugates with DNA quadruplex: FID assay and quantum-chemical modeling
}

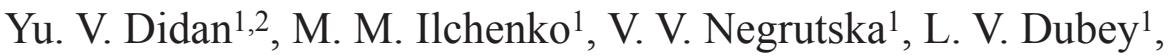 \\ O. A. Ryazanova ${ }^{3}$, I. Ya. Dubey ${ }^{1}$ \\ ${ }^{1}$ Institute of Molecular Biology and Genetics, NAS of Ukraine \\ 150, Akademika Zabolotnoho Str., Kyiv, Ukraine, 03143 \\ 2 Delft University of Technology \\ 9 van der Maasweg, Delft 2629HZ, Netherlands \\ ${ }^{3}$ B. I. Verkin Institute for Low Temperature Physics and Engineering, NAS of Ukraine \\ 47, Prospekt Nauky, Kharkiv, Ukraine, 61103 \\ dubey@imbg.org.ua
}

\begin{abstract}
Aim. To study the efficiency of tricationic porphyrin-imidazo[4,5-b]phenazine conjugate and its $\mathrm{Zn}(\mathrm{II})$ and $\mathrm{Mn}(\mathrm{III})$ complexes as G-quadruplex (G4) DNA ligands. Methods. FID (Fluorescent Intercalator Displacement) assay was used to evaluate the affinity of compounds for a model duplex and Tel22 quadruplex DNA at various ionic strengths. Molecular modeling of the conjugate interaction with G4 DNA was performed using the Density Functional Theory (DFT) calculations with M06-2X functional and 6-31G(d) basis set. Guanine octet stabilized with $\mathrm{K}^{+}$ion was used as a $\mathrm{G} 4$ model. Results. $\mathrm{DC}_{50}$ values and dissociation constants were determined for the complexes of three conjugates with duplex and quadruplex DNA. The structures and energetic parameters of G-octet complexes with Zn-metalated conjugate were obtained. Conclusions. All complexes have a strong affinity to the Tel22 quadruplex. The increase of ionic strength results in an increase in selectivity for quadruplex over duplex DNA and the decrease of binding affinity of the ligands. The structure of ligand-G4 complexes is determined by stacking interaction of porphyrin fragment with G-quartet, rather than an intercalative binging of the ligand.
\end{abstract}

Ke y w or d s: G-quadruplex, ligands, porphyrins, imidazophenazine, FID, DFT

\section{Introduction}

Quite recently established anticancer strategy is based on targeting the telomeres and telomerase by small molecules. Telomeres are guanine-rich DNA sequences located at the ends of the chromosomes. Telomeric DNA is able to fold into specific four-stranded structures called G-quadruplexes (G4) formed by the stacks of guanine quartets (G-quartets)

(C) 2018 Yu. V. Didan et al.; Published by the Institute of Molecular Biology and Genetics, NAS of Ukraine on behalf of Biopolymers and Cell. This is an Open Access article distributed under the terms of the Creative Commons Attribution License (http://creativecommons.org/licenses/by/4.0/), which permits unrestricted reuse, distribution, and reproduction in any medium, provided the original work is properly cited 
linked by non-canonical systems of hydrogen bonds and stabilized by monovalent metal cations located inside the channel formed by guanine residues [1, 2] (Fig. 1). Binding and stabilization of these structures by small molecules can result in the inhibition of telomerase, an enzyme responsible for telomere elongation upon cellular division [3, 4]. Telomerase is highly active in a majority (80-95\%) of tumor cells, in contrast to normal somatic cells $[3,5]$. So telomerase system is directly associated with cancer, and both telomerase and telomeric DNA quadruplex structures are considered as targets for the development of novel anticancer drugs [6-9].

In the cell, G4 structures are also found in promoter regions of some genes, mainly protooncogenes [10]. Stable RNA quadruplexes have been discovered as well [11]. There is growing evidence that DNA and RNA quadruplexes play a crucial biological role as a class of regulatory elements involved in processes such as DNA replication, transcription and translation $[12,13]$.
The binding of a ligand to telomeric G-quadruplex can interfere with telomerase interaction with telomeric DNA blocking its elongation and thus inducing the death of cancer cells $[2-4,8]$. Another mechanism of antitumor activity of G4 ligands has been shown to be quadruplex-mediated DNA damage [14, 15].

Usually specific G4 ligands contain large heteroaromatic systems allowing the efficient $\pi$ - $\pi$-interaction with G-quartets $[2,7-9,16]$. Tetracationic porphyrin TMPyP 1 (Fig. 1) is a well established G4 ligand and telomerase inhibitor $[17,18]$. Its tricationic analog tris(methylpyridinium)phenylporphyrin (TMP3) was used to attach porphyrin to a variety of other molecules [19-22]. We have previously synthesized TMP3 conjugate with imidazo[4,5-b]phenazine (TMP3-ImPhz) and their $\mathrm{Zn}$ (II) and $\mathrm{Mn}$ (III) complexes [23] (Fig. 2). ImPhz is an efficient intercalating agent stabilizing DNA duplexes [24-27], and its residue was expected to enhance ligand affinity for G4-DNA.

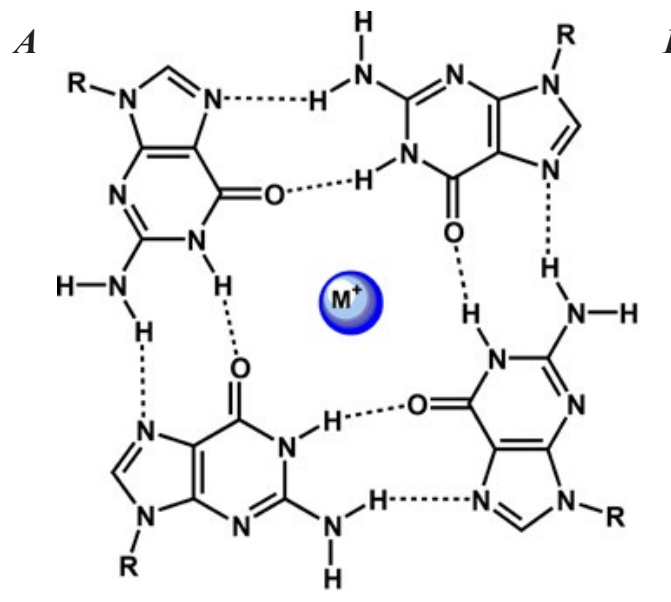

B

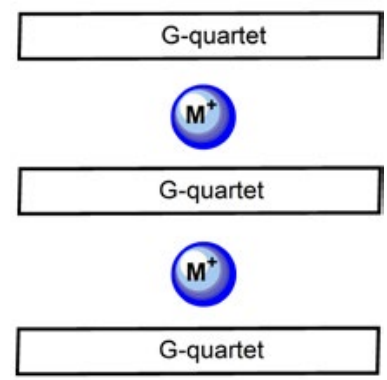

Fig. 1. (A) The structure of guanine quartet; (B) side view of the stack of three G-quartets containing two metal cations $\left(\mathrm{K}^{+}, \mathrm{Na}^{+}\right)$. 


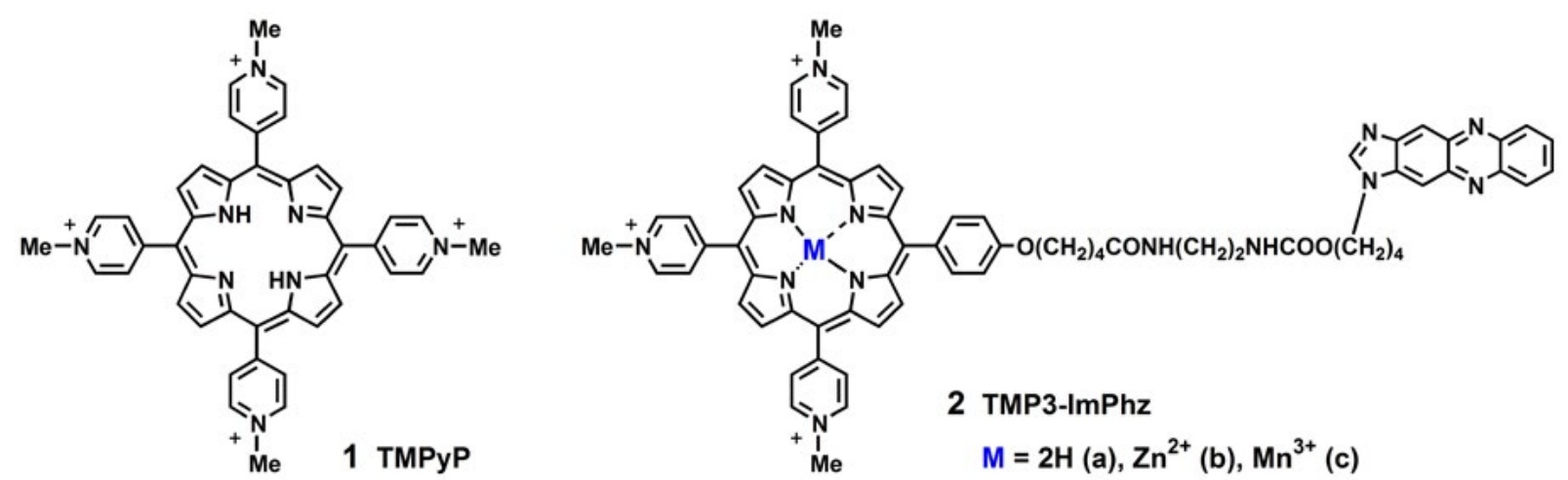

Fig. 2. The structure of cationic porphyrin derivatives.

Conjugates 2a-c were shown to be efficient telomerase inhibitors in vitro active at $2-10 \mu \mathrm{M}$ concentration [28]. They were also found to display antiproliferative activity in vitro (mouse Lewis lung carcinoma cell culture), with $\mathrm{EC}_{50}$ values for $\mathbf{2 a}$, its $\mathrm{Mn}$ and $\mathrm{Zn}$ complex to be 21.8, 11.2 and 5.9 $\mu \mathrm{M}$, respectively [23].

Absorption and fluorescence spectroscopy studies on the interaction of compounds $\mathbf{2 a - c}$ with monomolecular quadruplex Tel22 [29] and tetramolecular G4 formed by poly $(\mathrm{G})[30$, $31]$, as well as various double- and singlestranded nucleic acids [29-31], revealed a number of binding modes, including electrostatic interactions, external binding, aggregation and intercalation. However, binding parameters of these compounds to G4 and duplex DNA have not yet been determined.

In this work we have quantitatively evaluated the affinity and selectivity of porphyrinimidazophenazine conjugates as quadruplex DNA ligands and their possible mode of binding to G4 structure.

\section{Materials and Methods}

Sodium cacodylate and Thiazole Orange (TO) were obtained from "Sigma" (USA). Conju- gates of tricationic porphyrin TMP3 and its $\mathrm{Zn}$ (II) and Mn(III) complexes with imidazo[4,5-b]phenazine were synthesized as previously reported [23]. Oligonucleotides were from "Eurogentec" (Belgium).

DNA quadruplex was obtained by the folding of a model oligonucleotide Tel22 of the sequence 5'-AGGG(TTAGGG) 3 ]-3'. Tel22 solution in a $10 \mathrm{mM}$ sodium cacodylate buffer (pH 7.3) containing $100 \mathrm{mM} \mathrm{KCl}$ was heated at $95^{\circ} \mathrm{C}$ for $5 \mathrm{~min}$ and slowly cooled overnight to room temperature and then equilibrated for a day at $4^{\circ} \mathrm{C}$. DNA duplex ds 17 was prepared by standard procedure from complementary 17-mer oligonucleotides 5'-CCAGTTCGTAG TAACCC-3' and 5'-GGGTTACTACGAACT GG-3' [34, 35].

\section{FID assay}

Fluorescent Intercalator Displacement assay was used to study the conjugate binding to duplex [32, 33] and quadruplex [34-36] DNA with TO as a fluorescent dye.

FID titration experiments were performed in 96-well plastic microplates in semi-automatic mode with Synergy HT analyzer (BioTek, USA). For both quadruplex and duplex DNA, the mo- 
lar ratio DNA/TO was 3:1. The reaction mixtures (total volume $50 \mu \mathrm{L}$ ) contained 100 or $200 \mathrm{mM} \mathrm{KCl}, 10 \mathrm{mM}$ Na-cacodylate, $1 \mu \mathrm{M}$ TO, $3 \mu \mathrm{M}$ Tel 22 or ds 17 , and various concentrations of tested compounds (solution in dimethyl sulfoxide). The fluorescence of samples was measured at room temperature with $\lambda_{\text {ex }}=500 \mathrm{~nm}$ and $\lambda_{\mathrm{em}}=530 \mathrm{~nm}$. The data were processed with Gen5 software. The percent of fluorophore displacement $D$ was obtained for each concentration as follows: $D=100-\left[\left(F / F_{0}\right) \times 100\right]$, where $F$ and $F_{0}$ - fluorescence of DNA/TO complex in the presence and absence of a ligand, respectively. The plots of $D v s$. ligand concentration were built, from which $\mathrm{DC}_{50}$ values (ligand concentration required for $50 \%$ displacement of TO in dye-DNA complex) were obtained. Dissociation constants of complexes were determined using the Scatchard method from the plots of $D F v s . D F /[$ free ligand], where $D F$ is a difference between the relative fluorescence of $\mathrm{DNA} / \mathrm{TO}$ complex in the presence and absence of a ligand, and [free ligand] is a concentration of unbound ligand in the probe [32, 33]. Three independent experiments were performed for each ligand.

\section{Molecular modeling}

Quantum-chemical modeling of the interaction of ligands with G4 structures was performed by DFT (Density Functional Theory) approach using M06-2X functional [37] and 6-31G(d) basic set. The structures of all porphyrin conjugates have been previously optimized by the same method [23]. Guanine octet stabilized by a potassium cation was used as a simple model of G-quadruplex [38].

Complexes of (Zn)TMP3-ImPhz with G-octet were investigated. Full geometry op- timization was performed for the studied systems in water. The solvent effects were treated using the CPCM (Conductor-like Polarizable Continuum Model) method [39, 40]. Calculations were carried out with Gaussian 09 package (revision B.01) [41].

\section{Results and Discussion}

The synthesis of tricationic porphyrin-imidazophenazine conjugates containing a flexible linker (2a-c, Fig. 2) was based on the coupling of carboxyalkyl-modified porphyrin with aminoalkyl-functionalized phenazine derivative, as described in [23].

\section{Ligand affinity and selectivity}

Ligand interaction with two forms of DNA was studied using a Fluorescent Intercalator Displacement (FID) assay. FID is a simple and fast analytical method that allows to evaluate the DNA binding affinity and selectivity of low-molecular compounds. This assay proposed by Boger et al. in 2001 [32] is based on the loss of fluorescence of some dyes, usually Thiazole Orange (TO), upon their displacement from complexes with DNA by a ligand. TO is virtually non-fluorescent in a free state, whereas its complexes with DNA are highly fluorescent. Both duplex [32, $33,42-44]$ and quadruplex [34-36, 44-46] DNA, as well as RNA [47], can be used as targets.

22-mer oligonucleotide Tel22 (sequence 5'-AGGG(TTAGGG) 3 ]-3', a fragment of human telomeric DNA containing three telomeric repeats), was folded in the presence of $\mathrm{K}^{+}$cations to form G-quadruplex of parallel topology (PDB access code 1KF1). Model double-stranded DNA ds17 was formed by two 
complementary non-quadruplex-forming 17mer oligonucleotides.

To evaluate the effect of ionic strength on binding affinity and selectivity, FID experiments were performed in solutions containing 100 and $200 \mathrm{mM} \mathrm{KCl}$.

$\mathrm{DC}_{50}$ values were determined from displacement-concentration plots obtained in FID titration experiments (Fig. 3). $\mathrm{DC}_{50}$ parameter, compound concentration resulting in $50 \%$ fluorophore substitution in dye-DNA complex, is a measure of relative ligand affinity to DNA targets; the lower is $\mathrm{DC}_{50}$, the higher is binding efficiency of the ligand.

Dissociation constants of ligand-DNA complexes $\left(K_{\mathrm{d}}\right)$ were determined from the titration data for duplex and G4 DNA using the classic Scatchard analysis, according to $[32,33]$. Ligand affinity data are presented in Table 1.

It should be noted that $\mathrm{DC}_{50}$ values are directly obtained from the experiment and can be used for affinity ranking of a series of ligands in regard to a given DNA target. At the

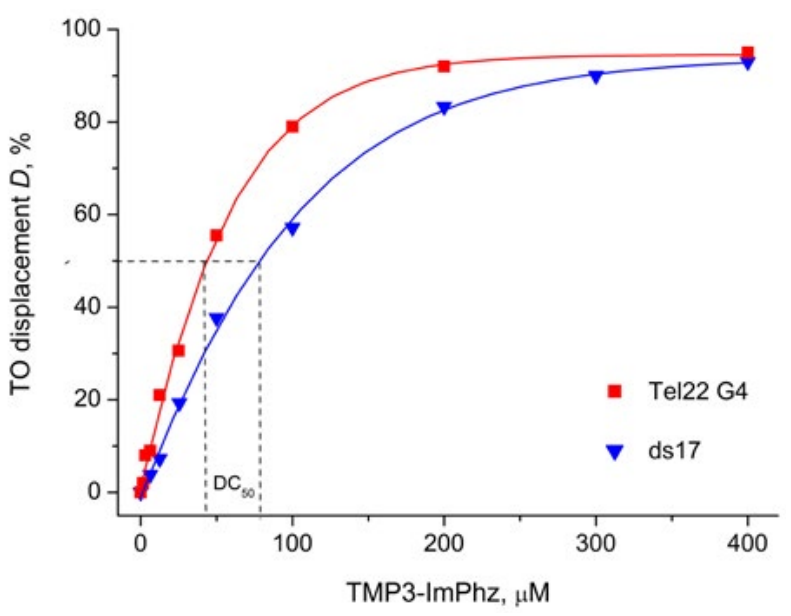

Fig. 3. FID titration plots obtained for non-metalated conjugate 2a with quadruplex (Tel22 G4) and duplex DNA (ds17) in $200 \mathrm{mM} \mathrm{KCl}$ buffer.

same time, $K_{\mathrm{d}}$ is a calculated parameter to be taken with care, since FID method is an indirect technique involving the competitive DNA binding of two ligands with different affinities and binding modes. FID and the direct methods provide comparable results [32, 45], but

Table 1. Binding parameters and selectivity indexes of TMP3-ImPhz and its metal complexes at various ionic strengths *

\begin{tabular}{|l|c|c|c|c|c|c|}
\hline \multirow{3}{*}{ Ligand } & \multicolumn{6}{|c|}{$100 \mathrm{mM} \mathrm{KCl}$} \\
\cline { 2 - 7 } & \multicolumn{3}{|c|}{$\mathrm{DC}_{50}, \mu \mathrm{M}$} & \multicolumn{2}{c|}{$K_{\mathrm{d}}, \times 10^{-6} \mathrm{M}$} & \multicolumn{2}{c|}{ Selectivity index ** } \\
\cline { 2 - 7 } & $\mathrm{G} 4$ & $\mathrm{ds} 17$ & $\mathrm{G} 4$ & $\mathrm{ds} 17$ & $\mathrm{SI}_{\mathrm{DC}}$ & $\mathrm{SI}_{\mathrm{K}}$ \\
\hline $\mathbf{2 a}$ & 17.4 & 5.0 & 4.6 & 3.7 & 0.29 & 0.81 \\
$\mathbf{2 b}$ & 36.1 & 59.7 & 7.0 & 6.1 & 1.65 & 0.87 \\
$\mathbf{2 c}$ & 14.4 & 14.2 & 1.6 & 2.9 & 0.99 & 1.81 \\
\hline & \multicolumn{7}{|c|}{$200 \mathrm{mM} \mathrm{KCl}$} & 1.82 & 4.45 \\
\hline 2a & 43.8 & 79.9 & 20.1 & 89.5 & 1.91 & 7.75 \\
2b & 59.6 & 114 & 46.3 & 359 & 2.53 & 11.1 \\
\hline 2c & 28.6 & 72.3 & 3.8 & 42.0 & & \\
\hline
\end{tabular}

* experimental errors are within $10 \%(\mathrm{n}=3)$

** $\mathrm{SI}_{\mathrm{DC}}=\mathrm{DC}_{50}(\mathrm{ds}) / \mathrm{DC}_{50}(\mathrm{G} 4) ; \mathrm{SI}_{\mathrm{K}}=K_{\mathrm{d}}(\mathrm{ds}) / K_{\mathrm{d}}(\mathrm{G} 4)$ 
some authors underline the difficulties in accurately determining DNA-ligand affinity constants, pointing out the need for comparing data obtained with various techniques [35].

All compounds demonstrate a strong binding to G4 DNA. Dissociation constants $K_{\mathrm{d}}$ in $100 \mathrm{mM} \mathrm{KCl}$ are in the range $(1.6-7.0) \times 10^{-6} \mathrm{M}$. The most efficient G4 binder is $\mathrm{Mn}$ (III) complex 2c. At high ionic strength $(200 \mathrm{mM} \mathrm{KCl})$ binding affinity of all ligands to G4 substantially decreases, according to both $\mathrm{DC}_{50}$ and $K_{\mathrm{d}}$ data, but remains high $\left.\left(K_{\mathrm{d}}=3.8-46.3\right) \times 10^{-6} \mathrm{M}\right)$.

High affinity of the conjugates for G4 is associated with a good ability to inhibit telomerase. The most efficient $\mathrm{Zn}$ (II) complex 2b was shown to completely inhibit it in vitro in TRAP assay [5] at $2.5 \mu \mathrm{M}$ concentration being several times more active than non-conjugated porphyrin. Non-metalated conjugate 2a showed inhibition effect at $5 \mu \mathrm{M}$, whereas $\mathrm{Mn}$ (III) derivative 2c was less active [28].

Preferential quadruplex $v s$. duplex binding, along with high affinity to quadruplex DNA, is a key requirement for specific antitumor G4 ligands allowing to minimize their unfavorable biological side effects. Selectivity index (SI) is defined as the ratio between either $\mathrm{DC}_{50}$ values or dissociation constants of ligands for duplex DNA and G4. At low $\mathrm{KCl}$ concentration $(100 \mathrm{mM})$ ligands $\mathbf{2 a}$ and $\mathbf{2 b}$ preferentially bind to duplex DNA, whereas Mn complex 2c has no (SI determined from $\mathrm{DC}_{50}$ values) or relatively low (SI based on $K_{\mathrm{d}}$ is 1.81) preference for $\mathrm{G} 4$.

At $200 \mathrm{mM} \mathrm{KCl}$ all ligands bind to G4DNA stronger than to duplex DNA, i.e. demonstrate a good selectivity for quadruplex over duplex DNA. For example, the selectivity index determined from $K_{\mathrm{d}}$ values is 4.45 for
TMP3-ImPhz and 7.75 and 11.1 for its $\mathrm{Zn}$ and Mn complexes, respectively. Thus, an increase in ionic strength leads to an increase of G4 selectivity of ligands.

Generally, both electrostatic and stacking interactions may contribute to DNA binding of the studied ligands. The electrostatic binding of positively charged porphyrin fragment to DNA phosphate backbone was experimentally shown to occur upon interaction of $\mathbf{2 a - c}$ with quadruplex structures [29-31]. Ionic strength increase suppresses strong, but nonspecific electrostatic interactions, resulting in the increase of ligand selectivity for G4, however, this effect is obviously associated with a decrease of binding affinity (Table 1). These data are in line with a recent finding that lowering the total charge on TMPyP decreases the affinity, but increases the selectivity to G4 vs. dsDNA [48].

\section{DFT modeling of complexes}

Computer modeling of the interaction of ligands with their molecular target, telomeric G-quadruplex, is required to get insights into their mechanism of action and for further structure optimization to design more potent telomerase inhibitors.

The complexity and flexibility of quadruplex structures is still a challenge for theoretical modeling of G4 and their ligand complexes. In addition to the large size of the molecular system, one of the main problems is a broad structural polymorphism of quadruplex DNA $[1,2,8,49]$.

Usually molecular modeling of quadruplex nucleic acids and their complexes is carried out by molecular dynamics (MD) approaches [50, 51]. For example, a series of cationic porphy- 
rin-anthraquinone hybrids have been investigated for their interaction with G4 DNA by employing docking and molecular dynamics methods [52]. MD simulations provide valuable information on conformation, dynamics and thermodynamic parameters of the systems studied. MD methods, however, have a number of limitations, e.g. force-field imperfections and often short simulation times resulting in insufficient accuracy of modeling. On the other hand, quantum-chemical (quantum-mechanical, QM) approaches are much more accurate, although require more computational resources, and have been successfully used in the field of quadruplex modeling [38, 53-55].

To find a possible mode of binding, we have performed a QM study of the interaction of metalated TMP3-ImPhz conjugate $\mathbf{2 b}$ with a simple model of G-quadruplex, so called G-octet previously developed by us [38]. This system consists of two guanine quartets containing a central $\mathrm{K}^{+}$cation. Molecular modeling was carried out to construct the geometries of complexes in aqueous solution. Calculations were performed by DFT approach using M06$2 \mathrm{X}$ functional [37] that was proposed for the correct description of non-covalent interactions, including the representation of geometry and energetic parameters of $\mathrm{p}$-stacking complexes [56]. Taking into account the comp- lexity of the studied system, we have used 6-31G(d) basic set.

A number of possible structures of the complexes have been identified (Fig. 4, Table 2). In all cases, the stacking interaction of the porphyrin ring with G-quartet is observed. ImPhz fragment can bind in several ways: it can freely move (structure A), interact with G-quartet (B) or porphyrin (C), or intercalate between the pair of quartets (D). The most energetically favorable structures are those where ImPhz residue interacts with G-quartet (B) or with a porphyrin (C), i.e. complexes in which both fragments of the conjugate participate in binding interactions. Of course, model structure B formed upon the conjugate binding to G-octet cannot be realized with a real Tel22 quadruplex containing 3 stacked G-quartets, due to the insufficient linker length. At the same time, the formation of intercalative complex D where imidazophenazine chromophore is inserted between two G-quartets is associated with strong deformation of G-octet that results in significant increase of system energy and its destabilization. So the intercalative mode of binding of ImPhz moiety is hardly possible. The same is true for the porphyrin fragment. It should be noted that metal cation located between G-quartets prevents ligands from efficient intercalation.

Table 2. Energetic parameters of (Zn)TMP3-ImPhz conjugate complexes with G-octet obtained with M06-2X/6-31G(d)/CPCM method.

\begin{tabular}{|l|c|c|c|c|}
\hline \multirow{2}{*}{$\begin{array}{c}\text { Energy, } \\
\mathrm{kCal} / \mathrm{mol}\end{array}$} & \multicolumn{4}{c|}{ Structure } \\
\cline { 2 - 5 } & $\mathrm{A}$ & $\mathrm{B}$ & $\mathrm{C}$ & $\mathrm{D}$ \\
\hline Total & -6523385.80 & -6523413.28 & -6523412.74 & -6523380.59 \\
Relative & 27.48 & 0.0 & 0.54 & 32.59 \\
\hline
\end{tabular}


$A$

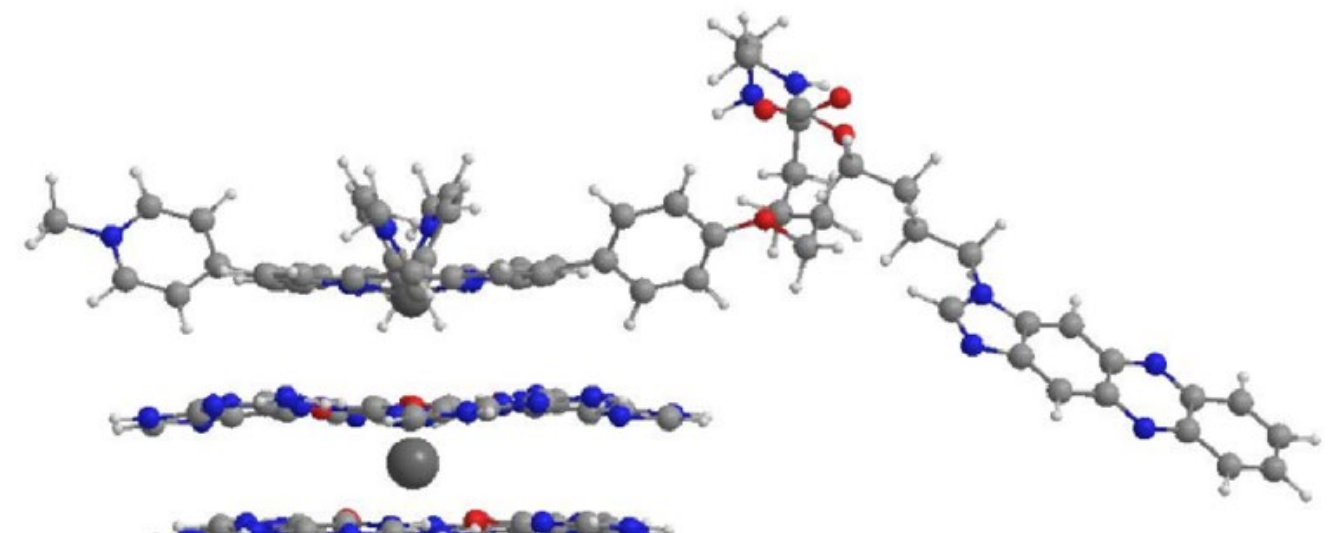

$\boldsymbol{B}$

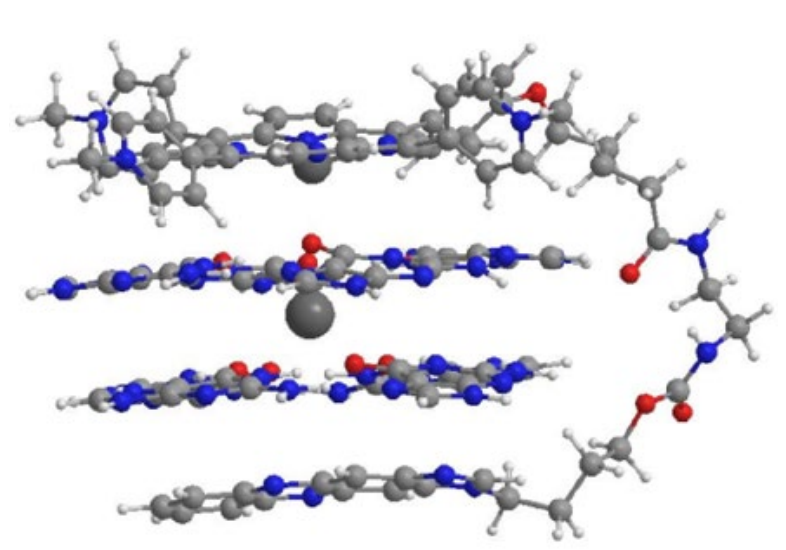

D

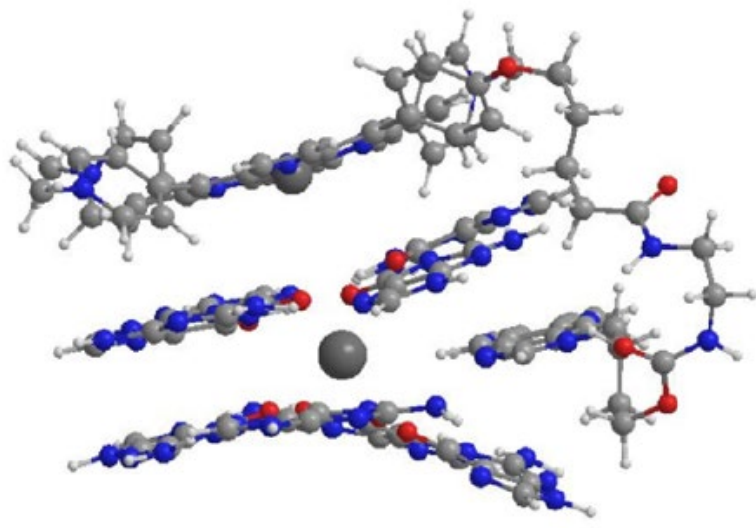

Importantly, both spectral-fluorescent data [29] and DFT calculations [23] suggest that free conjugate $\mathbf{2 a}$ and its $\mathrm{Zn}(\mathrm{II})$ complex $\mathbf{2 b}$ in
$C$

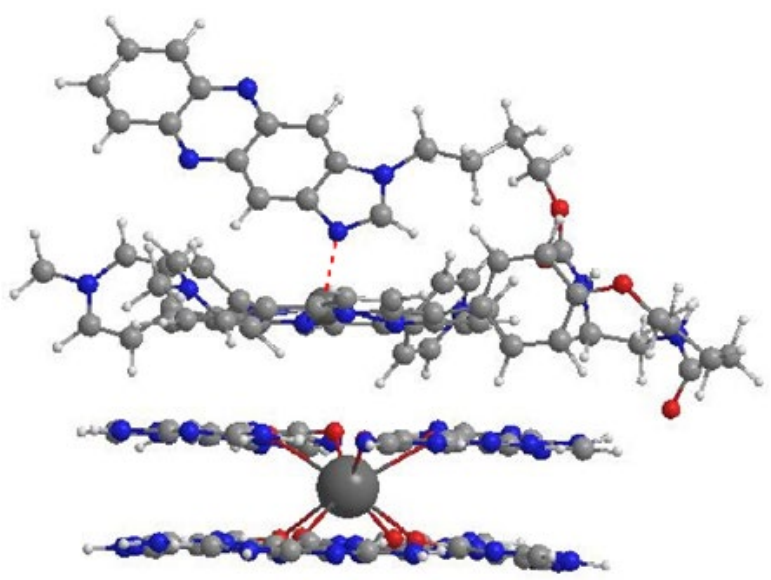

Fig. 4. DFT calculated structures of porphyrin-imidazophenazine $\mathbf{2 b}$ complexes with G-octet (side view). $\mathrm{N}-\mathrm{Zn}$ coordination bond in complex $\mathrm{C}$ is shown as a dashed line.

water exist mainly in the form of rather stable intramolecular head-to-tail heterodimers. Their formation results from the strong electronic 
interactions between porphyrin and $\mathrm{ImPhz}$ chromophores, via either p-p-stacking (2a) or metal coordination (2b). Moreover, it was shown by fluorescence spectroscopy techniques including the fluorescence polarization data that these conjugates can bind to G4 structures in the form of internal heterodimers [29-31], just as in case of the calculated complex $\mathrm{C}$.

Non-intercalative binding mode of the conjugates 2a-c to Tel22 quadruplex of antiparallel topology was proposed; non-metalated conjugate 2a was shown to bind to G4 via the interaction of porphyrin moiety with a terminal G-quartet, whereas the intercalative binding of phenazine moiety to Tel22 was not observed [29]. Phenazine intercalation between the guanine bases was observed only for the interaction of ( $\mathrm{Zn}$ )TMP3-ImPhz conjugate $\mathbf{2 b}$ with a long tetramolecular quadruplex formed by poly $(G)$ [31]. TMPyP itself was shown to bind to the parallel Tel22 via the external end-stacking rather than intercalation [18].

Thus, DFT modeling results are in good agreement with experimental data on the conjugate binding to Tel22 G4.

\section{Conclusion}

All studied compounds have a strong binding affinity for Tel22 quadruplex, with $K_{\mathrm{d}}$ values in micromolar range. Both binding affinity and selectivity of ligands depend on ionic strength of the solution. Its increase results in the decrease of ligand affinity for both duplex and G4 DNA. Interestingly, this decrease is associated with a significant increase of selectivity of compounds for G4 resulting presumably from the suppression of non-specific electrostatic interactions. Theoretical modeling has revealed that stacking interaction of
G-quartet with a porphyrin fragment, but not the intercalative binding of any conjugate component, determines the structure of ligand-G4 complexes.

\section{Acknowledgement}

Computational facilities were provided by the joint computer cluster of SSI Institute for Single Crystals and Institute for Scintillation Materials of the National Academy of Sciences of Ukraine [57].

\section{Funding}

This research was in part supported by the NAS of Ukraine program "Molecular and Cellular Biotechnologies for Medicine, Industry and Agriculture" (grant No. 43/18).

\section{REFERENCES}

1. Burge S, Parkinson GN, Hazel P, Todd AK, Neidle S. Quadruplex DNA: sequence, topology and structure. Nucleic Acids Res. 2006;34(19):5402-15.

2. $X u$ Y. Chemistry in human telomere biology: structure, function and targeting of telomere DNA/RNA. Chem Soc Rev. 2011;40(5):2719-40.

3. Ruden $M$, Puri $N$. Novel anticancer therapeutics targeting telomerase. Cancer Treat Rev. 2013;39(5):444-56.

4. Crees Z, Girard J, Rios Z, Botting GM, Harrington $K$, Shearrow $C$, Wojdyla L, Stone AL, Uppada SB, Devito JT, Puri N. Oligonucleotides and G-quadruplex stabilizers: targeting telomeres and telomerase in cancer therapy. Curr Pharm Des. 2014;20(41):6422-37.

5. Kim NW, Piatyszek MA, Prowse KR, Harley CB, West MD, Ho PL, Coviello GM, Wright WE, Weinrich SL, Shay JW. Specific association of human telomerase activity with immortal cells and cancer. Science. 1994;266(5193):2011-5.

6. Sekaran V, Soares J, Jarstfer MB. Telomere maintenance as a target for drug discovery. $J$ Med Chem. 2014;57(3):521-38. 
7. Maji B, Bhattacharya S. Advances in the molecular design of potential anticancer agents via targeting of human telomeric DNA. Chem Commun (Camb). 2014;50(49):6422-38.

8. Neidle $S$. Quadruplex nucleic acids as targets for anticancer therapeutics. Nat Rev Chem. 2017; 1(5):0041.

9. Islam MK, Jackson PJ, Rahman KM, Thurston DE. Recent advances in targeting the telomeric G-quadruplex DNA sequence with small molecules as a strategy for anticancer therapies. Future Med Chem. 2016;8(11):1259-90.

10. Rigo R, Palumbo $M$, Sissi $C$. G-quadruplexes in human promoters: A challenge for therapeutic applications. Biochim Biophys Acta Gen Subj. 2017;1861(5 Pt B):1399-1413.

11. Cammas A, Millevoi $S$. RNA G-quadruplexes: emerging mechanisms in disease. Nucleic Acids Res. 2017;45(4):1584-1595.

12. Rhodes D, Lipps HJ. G-quadruplexes and their regulatory roles in biology. Nucleic Acids Res. 2015;43(18):8627-37.

13. Hänsel-Hertsch R, Di Antonio M, Balasubramanian $S$. DNA G-quadruplexes in the human genome: detection, functions and therapeutic potential. Nat Rev Mol Cell Biol. 2017;18(5):279-284.

14. Hasegawa D, Okabe S, Okamoto K, Nakano I, Shinya $K$, Seimiya $H$. G-quadruplex ligand-induced DNA damage response coupled with telomere dysfunction and replication stress in glioma stem cells. Biochem Biophys Res Commun. 2016;471(1):75-81.

15. Moruno-Manchon JF, Koellhoffer EC, Gopakumar J, Hambarde S, Kim N, McCullough LD, Tsvetkov $A S$. The G-quadruplex DNA stabilizing drug pyridostatin promotes DNA damage and downregulates transcription of Brca1 in neurons. Aging (Albany NY). 2017;9(9):1957-1970.

16. Monchaud D, Teulade-Fichou MP. A hitchhiker's guide to G-quadruplex ligands. Org Biomol Chem. 2008;6(4):627-36.

17. Wheelhouse RT, Sun D, Han H, Han FX, Hurley LH. Cationic porphyrins as telomerase inhibitors: the interaction of tetra-(N-methyl-4-pyridyl)porphine with quadruplex DNA. J Am Chem Soc. 1998; 120(13):3261-62.
18. Han H, Langley DR, Rangan A, Hurley LH. Selective interactions of cationic porphyrins with G-quadruplex structures. J Am Chem Soc. 2001;123(37): 8902-13.

19. Mestre B, Pratviel G, Meunier B. Preparation and nuclease activity of hybrid "metallotris(methylpyridinium)porphyrin oligonucleotide" molecules having a 3'-loop for protection against 3'-exonucleases. Bioconjugate Chem. 1995; 6(4):466-72.

20. Mezo G, Herényi L, Habdas J, Majer Z, MyśliwaKurdziel B, Tóth K, Csik G. Syntheses and DNA binding of new cationic porphyrin-tetrapeptide conjugates. Biophys Chem. 2011;155(1):36-44.

21. Dixon IM, Lopez F, Estève JP, Tejera AM, Blasco MA, Pratviel G, Meunier B. Porphyrin derivatives for telomere binding and telomerase inhibition. Chembiochem. 2005;6(1):123-32.

22. Zhao P, Hu L-C, Huang J-W, Fu D, Yu H-C, Ji L-N. Cationic porphyrin-anthraquinone dyads: modes of interaction with G-quadruplex DNA. Dyes Pigments. 2009; 83(1):81-7.

23. Dubey LV, Ilchenko MM, Zozulya VN, Ryazanova OA, Pogrebnoy PV, Dubey IYa. Synthesis, structure and antiproliferative activity of cationic porphyrin-imidazophenazine conjugate. Int Rev Biophys Chem. 2011; 2(4):147-52.

24. Blagoi YuP, Zozulya VN, Voloshin IM, Makitruk VL, Shalamay AS, Shcherbakova AS. Investigation of phenazine derivatives interaction with DNA by polarized fluorescence method. Biopolym Cell. 1997; 13(1):22-9.

25. Zozulya V, Shcherbakova A, Dubey I. Calculating helix-to-coil transitions of duplexes formed by phenazine-conjugated oligonucleotide, using fluorescence melting data. J Fluorescence. 2000; 10(1):49-53.

26. Zozulya V, Blagoi Yu, Dubey I, Fedoryak D, Makitruk V, Ryazanova O, Shcherbakova A. Anchorage of an oligonucleotide hybridization by a tethered phenazine nucleoside analogue. Biopolymers. 2003; 72(4):264-73.

27. Dubey L, Ryazanova O, Zozulya V, Fedoryak D, Dubey I. Postsynthetic modification of oligonucleotides with imidazophenazine dye and its effect on 
duplex stability. Nucleosides Nucleotides Nucleic Acids. 2011;30(7-8):585-96.

28. Negrutska VV, Dubey LV, Ilchenko MM, Dubey IYa. Design and study of telomerase inhibitors based on G-quadruplex ligands. Biopolym Cell. 2013; 29(3):169-76.

29. Zozulya VN, Ryazanova OA, Voloshin IM, Dubey LV, Dubey IYa. Spectroscopic studies on binding of porphyrin-phenazine conjugate to intramolecular G-quadruplex formed by 22-mer oligonucleotide. Int Rev Biophys Chem. 2011; 2(4):112-9.

30. Ryazanova O, Zozulya V, Voloshin I, Dubey L, Dubey I, Karachevtsev V. Spectroscopic Studies on Binding of Porphyrin-Phenazine Conjugate to Four-Stranded Poly(G). J Fluoresc. 2015;25(4): 1013-21.

31. Ryazanova O, Zozulya V, Voloshin I, Dubey L, Dubey I, Karachevtsev V. Binding of Metallated Porphyrin-Imidazophenazine Conjugate to Tetramolecular Quadruplex Formed by $\operatorname{Poly}(\mathrm{G})$ : a Spectroscopic Investigation. J Fluoresc. 2015;25(6): 1897-904.

32. Boger DL, Fink BE, Brunette SR, Tse WC, Hedrick $M P$. A simple, high-resolution method for establishing DNA binding affinity and sequence selectivity. J Am Chem Soc. 2001;123(25):5878-91.

33. Boger DL, Tse WC. Thiazole orange as the fluorescent intercalator in a high resolution fid assay for determining DNA binding affinity and sequence selectivity of small molecules. Bioorg Med Chem. 2001;9(9):2511-8.

34. Monchaud D, Allain C, Teulade-Fichou MP. Development of a fluorescent intercalator displacement assay (G4-FID) for establishing quadruplex-DNA affinity and selectivity of putative ligands. Bioorg Med Chem Lett. 2006;16(18):4842-5.

35. Monchaud D, Allain C, Bertrand H, Smargiasso N, Rosu F, Gabelica V, De Cian A, Mergny JL, TeuladeFichou MP. Ligands playing musical chairs with G-quadruplex DNA: a rapid and simple displacement assay for identifying selective G-quadruplex binders. Biochimie. 2008;90(8):1207-23.

36. Largy E, Hamon F, Teulade-Fichou MP. Development of a high-throughput G4-FID assay for screening and evaluation of small molecules binding qua- druplex nucleic acid structures. Anal Bioanal Chem. 2011;400(10):3419-27.

37. Zhao Y, Truhlar DG. The M06 suite of density functionals for main group thermochemistry, thermochemical kinetics, noncovalent interactions, excited states, and transition elements: two new functionals and systematic testing of four M06-class functionals and 12 other functionals. Theor Chem Acc. 2008; 120(1):215-41.

38. Ilchenko MM, Dubey IYa. Density functional study of the structure of guanine octets in aqueous medium. Int Rev Biophys Chem. 2011; 2(3):82-6.

39. Barone V, Cossi M. Quantum calculation of molecular energies and energy gradients in solution by a conductor solvent model. J Phys Chem A. 1998; 102(11):1995-2001.

40. Cossi M, Rega N, Scalmani G, Barone V. Energies, structures, and electronic properties of molecules in solution with the C-PCM solvation model. J Comput Chem. 2003;24(6):669-81.

41. Frisch MJ, Trucks GW, Schlegel HB, Scuseria GE, Robb MA, Cheeseman JR, et al. Gaussian 16 Rev. B.01. Wallingford, CT2016.

42. Tse WC, Boger DL. A fluorescent intercalator displacement assay for establishing DNA binding selectivity and affinity. Acc Chem Res. 2004; 37(1):61-9.

43. Glass LS, Bapat A, Kelley MR, Georgiadis MM, Long EC. Semi-automated high-throughput fluorescent intercalator displacement-based discovery of cytotoxic DNA binding agents from a large compound library. Bioorg Med Chem Lett. 2010; 20(5):1685-8.

44. Del Villar-Guerra R, Gray RD, Trent JO, Chaires JB. A rapid fluorescent indicator displacement assay and principal component/cluster data analysis for determination of ligand-nucleic acid structural selectivity. Nucleic Acids Res. 2018;46(7):e41.

45. Tran PLT, Largy E, Hamond F, Teulade-Fichou M-P, Mergny $J-L$. Fluorescence intercalator displacement assay for screening G4 ligands towards a variety of G-quadruplex structures. Biochimie. 2011; 93(8): 1288-96.

46. Jamroskovic J, Livendahl M, Eriksson J, Chorell E, Sabouri N. Identification of compounds that selec- 
tively stabilize specific G-quadruplex structures by using a thioflavin T-displacement assay as a tool. Chem Eur J. 2016; 22(52):18932-43.

47. Asare-Okai PN, Chow CS. A modified fluorescent intercalator displacement assay for RNA ligand discovery. Anal Biochem. 2011;408(2):269-76.

48. Ruan TL, Davis SJ, Powell BM, Harbeck CP, Habdas $J$, Habdas P, Yatsunyk LA. Lowering the overall charge on TMPyP4 improves its selectivity for G-quadruplex DNA. Biochimie. 2017; 132:121-130.

49. Zhang $S$, Wu $Y$, Zhang $W$. G-quadruplex structures and their interaction diversity with ligands. ChemMedChem. 2014;9(5):899-911.

50. Sponer J, Cang X, Cheatham TE 3rd. Molecular dynamics simulations of G-DNA and perspectives on the simulation of nucleic acid structures. $\mathrm{Me}$ thods. 2012;57(1):25-39.

51. Haider $S$. Computational methods to study G-quadruplex-ligand complexes. J Ind Inst Sci. 2018; 98(3):325-39.

52. Arba M, Kartasasmita RE, Tjahjono DH. Molecular docking and dynamics simulations on the interaction of cationic porphyrin-anthraquinone hybrids with DNA G-quadruplexes. J Biomol Struct Dyn. 2016;34(2):427-38.

53. Bazzi S, Novotný J, Yurenko YP, Marek R. Designing a New Class of Bases for Nucleic Acid Quadruplexes and Quadruplex-Active Ligands. Chemistry. 2015;21(26):9414-25.

54. Zaccaria F, Paragi G, Fonseca Guerra C. The role of alkali metal cations in the stabilization of guanine quadruplexes: why $\mathrm{K}+$ is the best. Phys Chem Chem Phys. 2016; 18(31):20895-904.

55. Radhika R, Shankar R, Vijayakumar S, Kolandaivel $P$. Role of 6-Mercaptopurine in the potential therapeutic targets DNA base pairs and G-quadruplex DNA: insights from quantum chemical and molecular dynamics simulations. J Biomol Struct Dyn. 2018;36(6):1369-1401.

56. Hohenstein EG, Chill ST, Sherrill CD. Assessment of the performance of the M05-2X and M06-2X exchange-correlation functionals for noncovalent interactions in biomolecules. J Chem Theor Comput. 2008; 4(12):1996-2000.

\section{Взасмодія кон'югатів катіонного порфірину з імідазофеназином із ДНК-квадруплексом: метод FID та квантово-хімічне моделювання}

Ю. В. Дідан, М. М. Ільченко, В. В. Негруцька, Л. В. Дубей, О. О. Рязанова, І. Я. Дубей

Мета. Дослідити ефективність трикатіонного кон'югату порфірин-імідазо[4,5-b]феназин та його $\mathrm{Zn}(\mathrm{II})$ і $\mathrm{Mn}(\mathrm{III})$ комплексів як лігандів G-квадруплексної (G4) ДНК. Методи. Метод заміщення флуоресцентного інтеркалятора (FID) використано для оцінки афінності сполук до модельної дуплексної ДНК та квадруплексу Tel22 за різних значень іонної сили розчину. Молекулярне моделювання взаємодії кон'югату з G4-ДНК проведено за допомогою обчислень теорії функціоналу густини (DFT) з використанням функціоналу M06-2X та базисного набору 6-31G(d). Як модель G4 використано гуаніновий октет, стабілізований іоном $\mathrm{K}^{+}$. Результати. Визначено значення $\mathrm{DC}_{50}$ та константи дисоціації комплексів трьох кон'югатів із дуплексною та квадруплексною ДНК. Розраховано структури та енергетичні параметри комплексів G-октету з Zn-металізованим кон'югатом. Висновки. Всі сполуки виявляють високу афінність до квадруплексу Tel22. Збільшення іонної сили веде до зростання селективності до квадруплексної відносно дуплексної ДНК та зниження афінності зв'язування лігандів. Структуру комплексів ліганд-G4 визначає передусім стекінгова взаємодія порфіринового фрагмента 3 G-квартетом, а не інтеркаляційне зв'язування ліганда.

К л юч ч в і с л о в а: G-квадруплекс, ліганди, порфірини, імідазофеназин, FID, DFT

\section{Взаимодействие конъюгатов катионного порфирина с имидазофеназином с ДНК- квадруплексом: метод FID и квантово- химическое моделирование}

Ю. В. Дидан, Н. Н. Ильченко, В. В. Негруцкая, Л. В. Дубей, О. А. Рязанова, И. Я. Дубей

Цель. Изучить эффективность трикатионного конъюгата порфирин-имидазо[4,5-b]феназин и его Zn(II) и $\mathrm{Mn}(\mathrm{III})$ комплексов как лигандов G-квадруплексной (G4) ДНК. Методы. Метод замещения флуоресцент- 
ного интеркалятора (FID) использован для оценки аффинности соединений к модельной дуплексной ДНК и квадруплексу Tel22 при разных значениях ионной силы раствора. Молекулярное моделирование взаимодействия конъюгата с G4-ДНК проведено при помощи вычислений теории функционала плотности (DFT) с использованием функционала M06-2X и базисного набора 6-31G(d). В качестве модели G4 использован гуаниновый октет, стабилизированный ионом $\mathrm{K}^{+}$. Результаты. Определены значения $\mathrm{DC}_{50}$ и константы диссоциации комплексов трех конъюгатов с дуплексной и квадруплексной ДНК. Рассчитаны структуры и энергетические параметры комплексов G-октета с Zn-металлизированным конъ- югатом. Выводы. Все соединения проявляют высокую аффинность к квадруплексу Tel22. Увеличение ионной силы приводит к возрастанию селективности к квадруплексной относительно дуплексной ДНК и снижению аффинности связывания лигандов. Структуру комплексов лиганд-G4 определяет прежде всего стекинговое взаимодействие порфиринового фрагмента с G-квартетом, а не интеркаляционное связывание лиганда.

К л ю ч е в ы е с л о в а: G-квадруплекс, лиганды, порфирины, имидазофеназин, FID, DFT

Received 11.08.2018 